\title{
Endoplasmic Reticulum Stress as Therapeutic Target against Hypertension
}

\section{Cheang WS*}

Institute of Chinese Medical Sciences, University of Macau, China

*Corresponding author: Wai San Cheang, Institute of Chinese Medical Sciences, State Key Laboratory of Quality Research in Chinese Medicine, University of Macau, Macao SAR, China, Tel: : +853-8822 4914; Email: AnnaCheang@um.edu.mo

\section{Mini Review \\ Volume 3 Issue 3}

Received Date: August 06, 2019

Published Date: August 26, 2019

DOI: $10.23880 /$ oajpr-16000183

\section{Abstract}

Studies in the past decade have demonstrated that endoplasmic reticulum (ER) stress is closely associated with pathogenesis of hypertension. Signaling pathways involving AMP-activated protein kinase (AMPK) and NADPH-oxidase (Nox) have been identified to regulate ER stress; whilst ER stress contributes to the imbalance production between nitric oxide (NO) and reactive oxygen species (ROS). The present article reviews the protective effects and the potential therapeutic implication of ER stress inhibition by drugs or natural products in hypertension.

Keywords: Endoplasmic reticulum; Hypertension; Therapeutic

Abbreviations: ER: Endoplasmic Reticulum; TUDCA: Taurine-Conjugated Ursodeoxycholic Acid; FDA: Food and Drug Administration; VSMCs: Vascular Smooth Muscle Cells; SHRs: Spontaneous Hypertensive Rats; DOCA: Deoxycorticosterone-Acetate; COX: Cyclooxygenase; ACM: Angiotensin Converting Enzyme; MED: Methionine Enriched Diet; PAH: Pulmonary Arterial Hypertension; RV: Right Ventricular; DHA: Docosahexaenoic Acid.

\section{Introduction}

Endoplasmic reticulum (ER) is a crucial organelle in which protein synthesis, maturation, folding and trafficking take place. Only properly folded proteins can be destined to cellular organelles or cell surface; nevertheless, misfolded or unfolded proteins are retained in the ER to be degraded eventually [1]. Disruption of the aforementioned processes results in the accumulation of newly synthesized unfolded proteins in the ER and this condition is referred to as ER stress [2]. ER stress occurs in different pathological conditions, including ischemia, hypoxia, altered glycosylation, nutrient deprivation, oxidative stress and $\mathrm{Ca}^{2+}$ depletion of ER stores; and consequently activates ER membrane-associated proteins and complex downstream signaling pathways to regulate targeted gene expression [3]. Studies have demonstrated that chronic ER stress performs a role in the pathogenesis of diseases including atherosclerosis [4], hypertension [5], diabetes mellitus and obesity, as well as the associated vascular dysfunctions [6], neurological disorders [7] and cancer [8]. Moreover, several drugs and natural compounds have been identified to reduce ER stress and thereby show protective effects against ER stressassociated pathologies. The present article provides an overview of suppressing ER stress by drugs and natural products on the potential therapeutic implication against hypertension.

\section{Suppression of ER Stress Reverses the Pathogenesis in Hypertension}

Several evidence supports the implication of ER stress in hypertension and pharmacological inhibition of ER stress ameliorates the pathological conditions. Chemical 


\section{Open Access Journal of Pharmaceutical Research}

chaperones 4-phenyl butyric acid (4-PBA) and taurineconjugated ursodeoxycholic acid (TUDCA) are approved by US Food and Drug Administration (FDA) for treating urea cycle disorders and biliary cirrhosis respectively. Nox (NADPH-oxidase) subcellular compartmentalization contributes to oxidative and ER stress, resulting in increased proliferation of vascular smooth muscle cells (VSMCs), protein hyperoxidation and vascular dysfunction in hypertension; and 4-PBA attenuates hypercontractility and vascular reactive oxygen species (ROS) formation in the stroke-prone spontaneous hypertensive rats (SHRs) [9]. Oral administration of 4PBA lowers blood pressure, reduces vasoconstriction and enhances vasodilation in small mesenteric arteries from SHRs through inhibition of ER stress and oxidative stress [10]. Likewise, administration of TUDCA protects against deoxycorticosterone-acetate (DOCA) salt-induced hypertension and endothelial dysfunction in rats through reducing ER stress and apoptosis in blood vessels [11]. Similar results were obtained in hypertensive rats that ER stress inhibition by 4-PBA and TUDCA normalized blood pressure by suppressing $\mathrm{Ca}^{2+}$-dependent cytosolic phospholipase A2 (cPLA2)/ cyclooxygenase (COX) pathway [12]. Diabetes mellitus and hypertension are closely related and synergistically induce kidney injury through upregulation of ER stress; whilst TUDCA treatment reverses the blood pressure and kidney injury [13]. ER stress and apoptotic markers are upregulated in the heart from SHRs, revealing that ER stress is linked to myocardial apoptosis associated with hypertension [14]. Both TUDCA and 4-PBA can ameliorate cardiac fibrosis and macrovascular endothelial function via inhibition of transforming growth factor-beta 1 (TGF- $\beta 1$ ) pathway in angiotensin II (Ang II)-induced hypertensive mice [15]. In addition, ER stress in brain has been implicated in Ang IIinduced hypertension which can be reversed by treatment with TUDCA [16].

Apart from the common ER stress alleviators 4-PBA and TUDCA, other drugs and natural products have also been demonstrated to have beneficial effects in hypertension through inhibition of ER stress. Hyperhomocysteinemia is associated with hypertension and homocysteine (Hcy) is also well-known to induce ER stress [17]. Hcy induces cell death of vascular endothelial cells by activation of JNK and ATF3 through IRE1/TRAF2 pathway [18] and by eIF2 $\alpha$ induction of the T-cell associated gene 51 (TDAG51) [19]. Administration of enalapril, a common antihypertensive drug, reverses blood pressure and pathological changes including elevated plasma Hcy and angiotensin converting enzyme
(ACE) levels, and increased contractile response and ER stress in aortas in rats on methionine-enriched diet (MED) [20]. Furthermore, black tea consumption for 2 weeks has been found to reduce ER stress and oxidative stress in aortas and thereby ameliorate vascular dysfunction and normalize plasma Hcy level and blood pressure in hypertensive rats [21].

Studies have suggested that AMP-activated protein kinase (AMPK) is a physiological suppressor of ER stress. Apart from regulating systemic energy balance and metabolism [22], AMPK activation protects endothelial function which is attributed to inhibiting proliferation of VSMCs and increasing nitric oxide (NO) production from endothelial cells [23]. Pharmacological or genetic activation of AMPK has shown to mitigate ER stress in endothelial cells and enhance the endothelial-dependent relaxation in mouse aortas [24]. A widely-used antidiabetic drug metformin is well known to activate AMPK in different tissues in humans and rodents [25,26]. Recently, metformin has been found to decrease blood pressure by activating AMPK $\alpha 2$ and suppressing ER stress in VSMCs in Ang II-induced hypertensive mice [27]. Treating with JNK inhibitor SP600125 enhances neurological function and neuron survival via reduction of ER stress in hippocampal tissues from SHRs with cerebral ischemia [28].

\section{Inhibition of ER Stress Protects against Pulmonary Arterial Hypertension}

ER stress has been found to be activated in the vasculature of mice with hypoxia-induced pulmonary arterial hypertension (PAH); and administration of 4-PBA significantly reduced pulmonary hypertension, arterial remodelling and right ventricular (RV) hypertrophy [2931]. Of note, mice with conditional deletion of GATA-6, a member of the GATA family of zinc-finger transcription factors, in endothelial cells display elevation of ER stress markers and worsening of hypoxia-induced PAH [32]. This result reveals that endothelial cells play critical role for triggering ER stress in hypoxic mice. In peripheral blood mononuclear cells isolated from patients with limited cutaneous systemic sclerosis and PAH, ER stress markers are upregulated and in positive correlation with IL-6 level and severity of pulmonary artery pressure [33]. Moreover, daily treatment of docosahexaenoic acid (DHA) [34] and exogenous $\mathrm{H}_{2} \mathrm{~S}$ [35] attenuate $\mathrm{PAH}$ through inhibition of ER stress. Table 1 summarizes the beneficial effects of drugs or natural products with suppression of ER stress in different hypertensive models. 


\section{Open Access Journal of Pharmaceutical Research}

\begin{tabular}{|c|c|c|c|c|}
\hline $\begin{array}{c}\text { Drugs or } \\
\text { natural } \\
\text { products }\end{array}$ & Dosages & Effects & Animal models & References \\
\hline \multirow{3}{*}{ 4-PBA } & \multirow{3}{*}{$\begin{array}{c}1 \mathrm{~g} / \mathrm{kg} / \text { day, } 5 \text { weeks, } \\
\text { orally }\end{array}$} & $\bullet \downarrow$ blood pressure & \multirow{3}{*}{ SHRs } & \multirow{3}{*}[10]{} \\
\hline & & $\begin{array}{l}\text { - } \downarrow \text { contractility and } \uparrow \text { endothelium- } \\
\text { dependent relaxation in small mesenteric } \\
\text { arteries }\end{array}$ & & \\
\hline & & $\bullet \downarrow$ ER stress & & \\
\hline \multirow[t]{3}{*}{ 4-PBA } & \multirow{3}{*}{$\begin{array}{l}500 \mathrm{mg} / \mathrm{kg} / \text { day, } 4 \\
\text { weeks, orally }\end{array}$} & $\begin{array}{l}\text { - } \downarrow \text { pulmonary artery pressure, } \\
\text { pulmonary vascular resistance, } \\
\text { pulmonary artery remodeling, and RV } \\
\text { hypertrophy and } \uparrow \text { functional capacity }\end{array}$ & \multirow{3}{*}{$\begin{array}{l}\text { hypoxia-induced pulmonary } \\
\text { hypertensive mice and } \\
\text { monocrotaline (MCT)- } \\
\text { induced pulmonary } \\
\text { hypertensive rats }\end{array}$} & \multirow[t]{3}{*}[29]{} \\
\hline & & $\bullet \downarrow$ ER stress & & \\
\hline & & $\begin{array}{l}\downarrow \text { proliferation and } \uparrow a p o p t o s i s ~ i n \\
\text { pulmonary artery SMCs }\end{array}$ & & \\
\hline \multirow[t]{2}{*}{ 4-PBA } & \multirow{2}{*}{$\begin{array}{c}350-550 \mathrm{mg} / \mathrm{kg} / \mathrm{day} \\
4 \text { weeks, orally }\end{array}$} & $\begin{array}{l}\text { - } \downarrow R V \text { systolic pressure, RV hypertrophy } \\
\text { and pulmonary arterial muscularization }\end{array}$ & \multirow{2}{*}{$\begin{array}{l}\text { hypoxia-induced pulmonary } \\
\text { hypertensive mice }\end{array}$} & \multirow[t]{2}{*}[30]{} \\
\hline & & - $\downarrow$ ER stress and inflammation in lungs & & \\
\hline \multirow{3}{*}{ 4-PBA } & \multirow{3}{*}{$\begin{array}{l}500 \mathrm{mg} / \mathrm{kg} / \text { day, } 4 \\
\text { weeks, orally }\end{array}$} & $\begin{array}{l}\bullet \downarrow \text { mean pulmonary artery pressure and } \\
\text { RV systolic pressure }\end{array}$ & \multirow{3}{*}{$\begin{array}{l}\text { MCT-induced pulmonary } \\
\text { hypertensive rats }\end{array}$} & \multirow{3}{*}[31]{} \\
\hline & & - $\downarrow R V$ hypertrophy and remodeling & & \\
\hline & & $\begin{array}{l}\text { - } \quad \downarrow E R \text { stress and cardiomyocyte } \\
\text { apoptosis in RV }\end{array}$ & & \\
\hline \multirow{3}{*}{ TUDCA } & \multirow{3}{*}{$\begin{array}{l}150 \mathrm{mg} / \mathrm{kg} / \text { day, } 4 \\
\text { weeks, i.p. }\end{array}$} & $\begin{array}{l}\text { - } \downarrow \text { systolic blood pressure } \\
\text { endothelial dysfunction }\end{array}$ & \multirow{3}{*}{$\begin{array}{l}\text { DOCA salt-induced } \\
\text { hypertensive rats }\end{array}$} & \multirow{3}{*}[11]{} \\
\hline & & - $\uparrow$ plasma nitric oxide (NO) level & & \\
\hline & & - $\downarrow$ ER stress in aortas & & \\
\hline \multirow[t]{2}{*}{ TUDCA } & \multirow[t]{2}{*}{$\begin{array}{l}200 \mathrm{mg} / \mathrm{kg} / \text { day, } 6 \\
\text { weeks, s.c. }\end{array}$} & $\begin{array}{l}\text { - } \downarrow \text { blood pressure, albumin excretion, ER } \\
\text { and oxidative stress, and glomerular } \\
\text { injury }\end{array}$ & \multirow[t]{2}{*}{ Diabetic-hypertensive rats } & \multirow[t]{2}{*}{ [13] } \\
\hline & & - $\uparrow$ glomerular filtration rate & & \\
\hline \multirow{3}{*}{ enalapril } & \multirow{3}{*}{$\begin{array}{c}15 \mathrm{mg} / \mathrm{kg} / \text { day, } 30 \\
\text { days }\end{array}$} & - $\downarrow$ systolic blood pressure & \multirow{3}{*}{$\begin{array}{l}\text { MED-induced hypertensive } \\
\text { rats }\end{array}$} & \multirow{3}{*}[20]{} \\
\hline & & $\begin{array}{l}-\downarrow \text { Ang II-induced contractile response } \\
\text { and ER stress in aortas }\end{array}$ & & \\
\hline & & - $\downarrow$ plasma Hcy and ACE levels & & \\
\hline \multirow[b]{2}{*}{ metformin } & \multirow{2}{*}{$\begin{array}{l}300 \mathrm{mg} / \mathrm{kg} / \text { day, } 2 \\
\text { weeks, orally }\end{array}$} & - $\downarrow$ systolic and diastolic blood pressures & \multirow{2}{*}{$\begin{array}{l}\text { Ang II-induced hypertensive } \\
\text { mice }\end{array}$} & \multirow[b]{2}{*}[27]{} \\
\hline & & $\begin{array}{l}\text { - } \uparrow \text { phospholamban phosphorylation and } \\
\text { \ER stress in human VSMCs }\end{array}$ & & \\
\hline \multirow{4}{*}{$\begin{array}{l}\text { Black tea } \\
\text { extract }\end{array}$} & & - $\downarrow$ blood pressure & & \\
\hline & & - $\downarrow$ plasma Hcy level & & \\
\hline & $\begin{array}{l}15 \mathrm{mg} / \mathrm{kg} / \text { day, } 2 \\
\text { weeks, orally }\end{array}$ & $\begin{array}{l}\text { - } \uparrow \text { relaxations in aortas, carotid arteries, } \\
\text { mesenteric resistance arteries, and renal } \\
\text { arteries }\end{array}$ & $\begin{array}{l}\text { Ang II-induced hypertensive } \\
\text { rats }\end{array}$ & [21] \\
\hline & & $\begin{array}{l}\text { - } \downarrow \text { ER stress, ROS level and Hcy metabolic } \\
\text { enzymes in aortas }\end{array}$ & & \\
\hline DHA & $\begin{array}{l}100 \mathrm{mg} / \mathrm{kg} / \text { day, } 4 \\
\text { weeks, orally }\end{array}$ & $\begin{array}{l}\text { - } \downarrow \text { mean pulmonary arterial pressure, } \\
\text { pulmonary vascular remodeling and RV } \\
\text { hypertrophy }\end{array}$ & $\begin{array}{l}\text { MCT-induced pulmonary } \\
\text { hypertensive rats }\end{array}$ & [34] \\
\hline & & - $\downarrow$ ER stress & & \\
\hline
\end{tabular}




\section{Open Access Journal of Pharmaceutical Research}

\begin{tabular}{|c|c|c|c|c|}
\hline & & $\begin{array}{l}\text { - } \downarrow \text { inflammation in lung and adventitia of } \\
\text { resistance pulmonary arteries }\end{array}$ & & \\
\hline \multirow{5}{*}{$\begin{array}{c}\text { GYY4137 } \\
\left(\mathrm{H}_{2} \mathrm{~S} \text { donor }\right)\end{array}$} & \multirow{5}{*}{4 weeks, i.p. } & $\begin{array}{l}\text { - } \downarrow \text { mean pulmonary artery pressure and } \\
\text { total pulmonary resistance }\end{array}$ & \multirow{5}{*}{$\begin{array}{l}\text { hypoxia-induced pulmonary } \\
\text { hypertensive rats }\end{array}$} & \multirow{5}{*}{ [35] } \\
\hline & & $\begin{array}{l}\text { - } \downarrow \text { pulmonary artery remodeling and RV } \\
\text { hypertrophy }\end{array}$ & & \\
\hline & & - $\uparrow$ functional capacity & & \\
\hline & & - $\downarrow$ ER stress in pulmonary arteries & & \\
\hline & & $\begin{array}{l}\text { - } \downarrow \text { mitochondrial ROS and Nox4 levels in } \\
\text { pulmonary artery SMCs }\end{array}$ & & \\
\hline
\end{tabular}

Table 1: beneficial effects of drugs or natural products with suppression of ER stress in different hypertensive models.

\section{Conclusions}

Taken all together, increasing evidence proves the crucial role of ER stress in pathogenesis of hypertension. ER stress alleviators 4-PBA and TUDCA and drugs such as metformin and enalapril as well as natural products including DHA and black tea alleviate hypertension through suppression of ER stress. A better understanding of the cellular interactions of ER stress and other specific pathways in different vascular beds contributing to pathogenic condition will enhance the developing therapies to prevent or reverse hypertension.

\section{Acknowledgment}

This work was financially supported by Start-up Research Grant of University of Macau (SRG2019-00154ICMS).

\section{References}

1. Gething MJ, Sambrook J (1992) Protein folding in the cell. Nature 355: 33-45.

2. Hotamisligil GS (2010) Endoplasmic Reticulum Stress and the Inflammatory Basis of Metabolic Disease. Cell 140(6): 900-917.

3. Ma Y, Hendershot LM (2004) ER chaperone functions during normal and stress conditions. J Chem Neuroanat 28: 51-65.

4. Hotamisligil GS (2010) Endoplasmic reticulum stress and atherosclerosis. Nat Med 16(4): 396-399.

5. Hasty AH, Harrison DG (2012) Endoplasmic reticulum stress and hypertension - a new paradigm?. J Clin Invest 122(11): 3859-3861.
6. Zhang K, Kaufman RJ (2008) From endoplasmicreticulum stress to the inflammatory response. Nature 454: 455-462.

7. Penke B, Bogar F, Fulop L (2016) Protein Folding and Misfolding, Endoplasmic Reticulum Stress in Neurodegenerative Diseases: in Trace of Novel Drug Targets. Curr Protein Pept Sci 17(2): 169-182.

8. Urra H, Dufey E, Avril T, Chevet E, Hetz C (2016) Endoplasmic Reticulum Stress and the Hallmarks of Cancer. Trends Cancer 2(5): 252-262.

9. Camargo LL, Harvey AP, Rios FJ, Tsiropoulou S, Da Silva RNO, et al. (2018) Vascular Nox (NADPH Oxidase) Compartmentalization, Protein Hyperoxidation, and Endoplasmic Reticulum Stress Response in Hypertension. Hypertension 72(1): 235246.

10. Carlisle RE, Werner KE, Yum V, Lu C, Tat V, et al. (2016) Endoplasmic reticulum stress inhibition reduces hypertension through the preservation of resistance blood vessel structure and function. J Hypertens 34(8): 1556-1569.

11. Han S, Bal NB, Sadi G, Usanmaz SE, Tuglu MM, et al. (2019) Inhibition of endoplasmic reticulum stress protected DOCA-salt hypertension-induced vascular dysfunction. Vascul Pharmacol 113: 38-46.

12. Spitler KM, Matsumoto T, Webb RC (2013) Suppression of endoplasmic reticulum stress improves endothelium-dependent contractile responses in aorta of the spontaneously hypertensive rat. Am J Physiol Heart Circ Physiol 305(3): H344-353.

13. Wang Z, do Carmo JM, Aberdein N, Zhou X, Williams $\mathrm{JM}$, et al. (2017) Synergistic Interaction of 


\section{Open Access Journal of Pharmaceutical Research}

Hypertension and Diabetes in Promoting Kidney Injury and the Role of Endoplasmic Reticulum Stress. Hypertension 69(5): 879-891.

14. Sun Y, Zhang T, Li L, Wang J (2015) Induction of apoptosis by hypertension via endoplasmic reticulum stress. Kidney Blood Press Res 40(1): 41-51.

15. Kassan M, Galan M, Partyka M, Saifudeen Z, Henrion D, et al. (2012) Endoplasmic Reticulum Stress Is Involved in Cardiac Damage and Vascular Endothelial Dysfunction in Hypertensive Mice. Arterioscl Throm Vas 32(7): 1652-1661.

16. Young CN, Cao X, Guruju MR, Pierce JP, Morgan DA, et al. (2012) ER stress in the brain subfornical organ mediates angiotensin-dependent hypertension. J Clin Invest 122(11): 3960-3964.

17. Outinen PA, Sood SK, Pfeifer SI, Pamidi S, Podor TJ, et al. (1999) Homocysteine-induced endoplasmic reticulum stress and growth arrest leads to specific changes in gene expression in human vascular endothelial cells. Blood 94(3): 959-967.

18. Zhang C, Cai Y, Adachi MT, Oshiro S, Aso T, Kaufman RJ, et al. (2001) Homocysteine induces programmed cell death in human vascular endothelial cells through activation of the unfolded protein response. J Biol Chem 276(38): 35867-35874.

19. Hossain GS, van Thienen JV, Werstuck GH, Zhou J, Sood SK, et al. (2003) TDAG51 is induced by homocysteine, promotes detachment-mediated programmed cell death, and contributes to the development of atherosclerosis in hyperhomocysteinemia. Journal of Biological Chemistry 278(32): 30317-30327.

20. Zhou Y, Zhao L, Zhang Z, Lu X (2015) Protective Effect of Enalapril against Methionine-Enriched DietInduced Hypertension: Role of Endoplasmic Reticulum and Oxidative Stress. Biomed Res Int 2015: 724876 .

21. Cheang WS, Ngai CY, Tam YY, Tian XY, Wong WT, et al. (2015) Black tea protects against hypertensionassociated endothelial dysfunction through alleviation of endoplasmic reticulum stress. Sci Rep 5: 10340.

22. Kahn BB, Alquier T, Carling D, Hardie DG (2005) AMPactivated protein kinase: ancient energy gauge provides clues to modern understanding of metabolism. Cell Metab 1(1): 15-25.

23. Towler MC, Hardie DG (2007) AMP-activated protein kinase in metabolic control and insulin signaling. Circ Res 100(3): 328-341.

24. Dong Y, Zhang M, Wang S, Liang B, Zhao Z, et al. (2010) Activation of AMP-activated protein kinase inhibits oxidized LDL-triggered endoplasmic reticulum stress in vivo. Diabetes 59(6): 1386-1396.

25. Hundal RS, Krssak M, Dufour S, Laurent D, Lebon V, et al. (2000) Mechanism by which metformin reduces glucose production in type 2 diabetes. Diabetes $49(2)$ : 2063-2069.

26. Gundewar S, Calvert JW, Jha S, Toedt-Pingel I, Ji SY, et al. (2009) Activation of AMP-activated protein kinase by metformin improves left ventricular function and survival in heart failure. Circ Res 104(3): 403-411.

27. Duan Q Song P, Ding Y, Zou MH (2017) Activation of AMP-activated protein kinase by metformin ablates angiotensin II-induced endoplasmic reticulum stress and hypertension in mice in vivo. Br J Pharmacol 174(3): 2140-2151.

28. Zhao YN, Li JM, Chen CX, Zhang P, Li SX (2015) Hypertension-mediated enhancement of JNK activation in association with endoplasmic reticulum stress in rat model hippocampus with cerebral ischemia-reperfusion. Genet Mol Res 14(3): 1098010990.

29. Dromparis P, Paulin R, Stenson TH, Haromy A, Sutendra G, et al. (2013) Attenuating endoplasmic reticulum stress as a novel therapeutic strategy in pulmonary hypertension. Circulation 127(1): 115125.

30. Koyama M, Furuhashi M, Ishimura S, Mita T, Fuseya T, Okazaki Y, et al. (2014) Reduction of endoplasmic reticulum stress by 4-phenylbutyric acid prevents the development of hypoxia-induced pulmonary arterial hypertension. Am J Physiol Heart Circ Physiol 306(9): H1314-1323.

31. Wang JJ, Zuo XR, Xu J, Zhou JY, Kong H, et al. (2016) Evaluation and Treatment of Endoplasmic Reticulum (ER) Stress in Right Ventricular Dysfunction during Monocrotaline-Induced Rat Pulmonary Arterial Hypertension. Cardiovasc Drugs Ther 30(6): 587-598. 
32. Ghatnekar A, Chrobak I, Reese C, Stawski L, Seta F, et al. (2013) Endothelial GATA-6 Deficiency Promotes Pulmonary Arterial Hypertension. Am J Pathol 182(2): 2391-2406.

33. Lenna S, Farina AG, Martyanov V, Christmann RB, Wood TA, et al. (2013) Increased expression of endoplasmic reticulum stress and unfolded protein response genes in peripheral blood mononuclear cells from patients with limited cutaneous systemic sclerosis and pulmonary arterial hypertension. Arthritis Rheum 65(5): 1357-1366.
34. Chen R, Zhong W, Shao C, Liu P, Wang C, et al. (2018) Docosahexaenoic acid inhibits monocrotalineinduced pulmonary hypertension via attenuating endoplasmic reticulum stress and inflammation. Am J Physiol Lung Cell Mol Physiol 314(2): L243-L255.

35. Wu J, Pan W, Wang C, Dong H, Xing L, et al. (2019) $\mathrm{H} 2 \mathrm{~S}$ attenuates endoplasmic reticulum stress in hypoxia-induced pulmonary artery hypertension. Biosci Rep 39(7). 